\title{
Analysis of Creating Shared Value in the Food and Beverage Industry
}

\author{
Erwin Saraswati ${ }^{1 *}$
}

\section{AFFILIATION:}

${ }^{1}$ Faculty of Economics and Business, Universitas Brawijaya, Indonesia

*CORRESPONDENCE:

erwin_saraswati@yahoo.com

THIS ARTICLE IS AVAILABLE IN:

https://ojs.unud.ac.id/index.php/jiab

DOI:

10.24843/JIAB.2021.v16.i01.p10

CITATION:

Saraswati, E. (2021). Analysis of Creating Shared Value in the Food and Beverage Industry. Jurnal Ilmiah Akuntansi dan Bisnis, 16 (1), 154-162.

\section{ARTICLE HISTORY}

Received:

23 September 2020

Revised:

14 January 2020

Accepted:

15 January 2020

\begin{abstract}
This study analyzed the creating shared value (CSV) concept in the food and beverage industry using descriptive quantitative method Thirteen listed food and beverage companies in Indonesia from 2015 to 2017 were analyzed, resulting in 39 firm-year observations. We conducted a content analysis on the sample CSR reports using Drozdz et al.'s (2015) indicators. Our analysis showed that companies created value mostly for their customers, since customers are especially important for these firms because of their prominent nature. The result supports the legitimacy theory, which stated that companies need to align their operations with the expectations of the society they operate in order to survive. In addition, the result suggests that food and beverage companies need to start creating more shared values for the society, their employees, the environment, and their suppliers.
\end{abstract}

Keywords: created shared value, corporate social responsibility disclosures, food and beverage

\section{Introduction}

Most companies have practiced Corporate Social Responsibility (CSR) to gain legitimacy by improving their social values. However, by Creating Shared Value (CSV), a company can as well improve its economic value (Porter \& Kramer, 2011; Rachmawati et al., 2019; Shukla, 2016). The concept of creating shared value (CSV) was introduced by Porter and Kramer (2011) and has attracted considerable attention from the business world and also as an academic debate (Crane et al., 2014; Moczadlo, 2015).

The concept of CSV symbolizes a way for companies to maintain their economic focus but integrate societal and environmental concerns into their business model (Giesen, 2019). The idea of CSV is to provide a bridge between societal and economic growth (Porter \& Kramer, 2011). CSV sees that a company can enhance its competitiveness when they have a positive impact on the society they operate in (Lapina et al., 2012). CSV is seen as a renewed version of CSR (Sinthupundaja \& Kohda, 2019).

Corporate Social Responsibility (CSR) has been the company's responsibility to society to give the best service for stakeholders. In the beginning, CSR was considered as the philanthropic of a company, which means donation given by the company to the community is for improvement purpose; however, CSR scenario is an issue that is widely 


\section{Saraswati}

Creating Shared Value in the Food and Beverages Industry

researched and discussed throughout the world (Alpana, 2014). Currently, CSR has become a strategy, although some researchers have found that CSR is only a commitment (Adams \& Evans, 2004; Gray, 2010) in seeking a form of legitimacy.

Porter \& Kramer (2011) argue that CSR is different from CSV, especially in three ways. Firstly, CSR provides a value of "doing good" while CSV provides value; secondly, integrating the company's economic activities and, lastly, part of society. The problem is, sometimes CSR carried out by companies is not related to the company's main business activities (Macagno, 2013). The company ignores materiality, which is emphasized by Global Reporting Initiative (GRI) in GRI G4. Based on the CSV concept, companies maximize profits and integrate economic value and social benefits (Porter \& Kramer, 2011). CSV integrates social issues and challenges into economic value creation (Porter, 2013). Shared value opens up new needs, new markets, new value chain configurations, and new thinking about business (Porter, 2013).

CSR's downside is that fulfilling societal expectations is considered a constraint, or a cost, to the company, which harms the company's profits (Porter \& Kramer, 2011; Sinthupundaja \& Kohda, 2019). Meanwhile, CSV sees them as opportunities or a longterm investment (Lapina et al., 2012) and forms an integral part of a firm's profit maximization strategy (Kreckova, 2015; Lapina et al., 2012; Porter \& Kramer, 2011). CSV can create more demand, improve customer loyalty, increase productivity, and create a supportive environment, leading to business growth (Porter \& Kramer, 2011; Prasertsang, 2016). Wójcik (2016) wrote that while CSR uses economic value to create social value, CSV creates economic value while creating social value.

While CSR sees the society and environment as an external party to the company, CSV sees them as an integral part (Lapina et al., 2012; Porter \& Kramer, 2011; Shukla, 2016). As a result, CSV's agenda is more aligned to a company's core business, as opposed to CSR's agenda which is often externally derived and unrelated to the primary business activities of a company (Macagno, 2013; Porter \& Kramer, 2011; Porter \& Kramer, 2006). CSV sees the societal needs from a business's point of view, creating an intersection between societal needs and the company's competitive advantage (Scagnelli \& Cisi, 2014). CSR is done voluntarily and it is not directly related to profitability, productivity, and competitive advantage, whereas CSV is integrated with core products and services of corporations, therefore, directly linked to profitability, productivity, and competitive advantage (Islam \& Hossain, 2019).

For the last decade, the CSV concept has been studied worldwide, mostly in qualitative studies examining how companies apply the concept. Enel Green Power company shared value by educating senior members of society to install and maintain solar photovoltaic systems in less developed countries, while Snam Rete Gas conducted its CSV by sharing a platform of insights and know-how about best business practices with its supply chain and conducting workshops about workplace health and safety for its suppliers (Scagnelli \& Cisi, 2014).

Alpana (2014) found that India's healthcare and sanitation, agriculture, and finance sectors have also conducted CSV activities. While Brazilian agricultural companies have a project that was aimed at increasing the social-eco-efficiency in the value chain (Spitzeck \& Chapman, 2012). CSV's application on a national scale, however, has not been widely examined in the studies. The previous study by Lapina et al. (2012) 
examined the publicly available information in Latvian companies' annual reports and found that CSR and CSV's application has become increasingly popular over the years.

The food and beverage industry play an important role in the Indonesian economy since Indonesian households spend 50 percent of their income on food and beverages (Setiawan \& Lansink, 2017). The characteristics of food and beverage companies in Indonesia are among the strongest products in facing free-market competition, especially the ASEAN Economic Community (Masyarakat Ekonomi ASEAN or MEA) (Kemenperin, 2016). This is because the number of tourists continues to increase, and food and beverage are expected to increase linearly. In 2017, it is expected to grow by $8 \%$ (Kemenperin, 2017) and $9 \%$ in 2019 (Kemenperin, 2020). Unfortunately, food and beverage companies are classified as high risk and sensitive to economic fluctuations. Hence, this industry has great public visibility, requiring them to go the extra mile to legitimize society's position. The food and beverage industry are included in the top ten high-waste industries (GICS, 2014), because the packaging is not environmentally friendly, namely in the form of packaging and straws.

This study aims to apply and analyze the concept of CSV by Porter \& Kramer (2011), to know shared values CSR conducted by the company. CSV research is relatively rare, due to its not yet popular practice in Indonesia. We will analyze company CSR reports using the guideline from Drozdz et al. (2015). This study will use the legitimacy theory to explain that companies' motivation for CSV practices is to gain legitimacy from the society. This research analyzes CSR reports based on GRI G4, released in Indonesia in 2014 and mandatory since 2015 . So, this year is taken as a starting point until the data were fully available in 2017.

\section{Research Method}

This study is exploratory research using the descriptive quantitative method to explain CSV application in the food and beverage companies. The descriptive quantitative method systematically describes specific topics occurring in a particular object (Sekaran, 2016). The topic in this research is CSV, while the object is the food and beverage industry in Indonesia. We collected the data using content analysis method, by comparing the CSV components in Drozdz et al. (2015) with company reports.

The data used in this study were secondary data from the publicly available sustainability reports using the GRI G4 guideline because GRI is a comprehensive and balanced guideline in economic, social and environmental terms. GRI G4 was released in 2014 in Indonesia and recommended to be implemented in 2015. GRI standards were released in Indonesia in 2017 and must be implemented in 2018. Therefore, researchers analyzed the sustainability reports in 2015-2017. Food and beverage are a product that supports the needs of almost everyone and restaurants. The Ministry of Industry expected to grow by $8 \%$ in 2017 and $9 \%$ in 2019, for the food and beverage. The population consisted of 17 food and beverage industry firms listed on the Indonesian Stock Exchange from 2015 to 2017. The population was based on our search through the Indonesian Capital Market Directory (ICMD). Then we conducted sampling as shown in Table 1.

The number of samples per year was 13 companies, and the research period covered three years from 2015 to 2017, so the total number of samples come to 39 firmyear observations. 
Saraswati

Creating Shared Value in the Food and Beverages Industry

Table 1. Sample Selection

\begin{tabular}{lr}
\hline \multicolumn{1}{c}{ Criteria } & Number of firms \\
\hline Food and beverage firms & 17 \\
Incomplete data (not using GRI G4) & $(4)$ \\
Number of samples per year & 13 \\
Total samples (3 years) & 39 \\
\hline
\end{tabular}

Source: Processed Data, 2020

The Shared value defined as "corporate policies and practices that enhance the competitiveness of a company while simultaneously advancing the social and economic conditions of the communities in which the company sells and operates" (Porter \& Kramer, 2011). We measured shared value with the publicly available information in the companies' CSR reports with GRI G4 guideline, using a content analysis method. The researcher using 12 indicators from Drozdz et al. (2015) and analyzed four groups. Company sustainability reports will be analyzed with certain keywords according to the indicators, with a scoring of 1 when available and 0 when not available.

Drozdz et al. (2015) has classified into four groups based on concept of Porter \& Kramer (2011). Through a shared value strategy, environmental impact, suppliers, workforce skills, worker safety, workforce health, and water and energy use. Porter \& Kramer (2011) emphasize targeted social and economic concerns. Twelve indicators will be classified, each with different shared value indicators such as 1) employees: employee safety, employee health, employee skills; 2) environment: recycling, energy use, water use; 3) supplier: fair procurement, sharing of resources, support of supplier productivity. 4) customers: nutrition, service, and social value.

Group one is an employee group consisting of employee safety, employee health and employee skills. Porter \& Kramer (2011) state that employees provide share value which indirectly impacts the company's gain. For example, employee health will be able to work well and increase productivity.

Group two for the environment consists of recycling, energy use, and water use, which share values for the environment. If the company pays attention to energy and water use, it can reduce costs which are expected to increase performance. Food and beverage produce relatively significant plastic waste, including plastic straw reaching $16 \%$ and plastic packaging waste by $11 \%$ (Green Peace Indonesia, 2019), so that recycling packaging needs to be considered.

The supplier group consists of fair procurement, sharing of resources, support of supplier productivity. Sharing with suppliers can help share value for the company in terms of good material, higher quality, reduced risk and reduced cost (Drozd et al., 2015). The last group relates to customers consisting of nutrition, service, and social value as defined by Drozd et al., (2015).

\section{Result and Discussion}

We analyzed the shared values from 13 food and beverages companies from 2015 to 2017, or 39 firm-year observations in total. We collected the data using content analysis method, by comparing the CSV components in Drozdz et al. (2015) with company sustainability reports.

The results showed that all companies analyzed revealed service and social values, followed by employee health and safety indicators. Only one company disclosure 


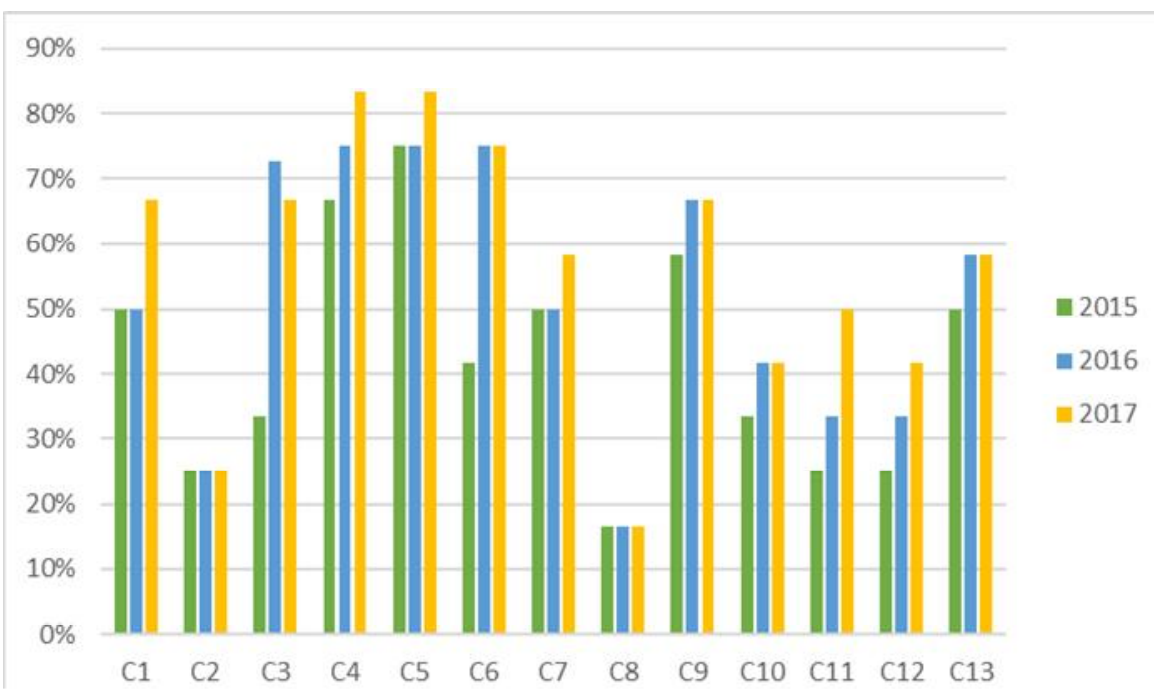

Figure 1. Shared Values by Company

Source: Processed Data, 2020

Notes: C1-C13 it means Company 1, 2,3, and so on for three years, 2015-2017. The percentage shows how many CSV indicators are disclosed in the company Sustainability Report.

about the sharing of resource and three company explain about recycling. Based on the four shared value indicators, the highest category expressed was customers, followed by employees, the environment and the lowest was the supplier group. The customer category is the highest CSR disclosure, indicating that CSR company activities is doing good, not doing well like CSV.

Based on the results that analysis of Food and Beverage Companies in Indonesia supports the legitimacy theory that companies carry out CSR activities and disclose them to legitimate stakeholders. Figure 1. reveals the shared values by company. We analyzed the CSV by classifying the items into four groups (employees, environment, suppliers, and customers).

The data shows that most companies increased or maintained their shared values disclosure each year. This shows that there is a growing interest in the CSV initiatives from companies. The overall average was 50 percent. This means that an average company will disclose six out of 12 shared value categories in a given year.

However, no company fully disclosed all indicators of CSV. The highest scorers, Company 4 and 5, have a parent-subsidiary relationship. They disclosed 10 out of the 12 in 2017, with the two undisclosed indicators being the sharing of resources and support for the supplier's productivity, both of which belong in the supplier category.

The only firm with a decline in its disclosures during the observation period was Company 3. It started disclosing its energy use in 2016, but stopped disclosing this the following year. The lowest results were from Company 8 and 2, neither of which showed any increase or decrease in their disclosures each year. Company 8 only disclosed two out of the 12 indicators during the research period: service and social value which belong to the customer group. This suggests that the company only created shared value for their customers. 


\section{Saraswati}

Creating Shared Value in the Food and Beverages Industry

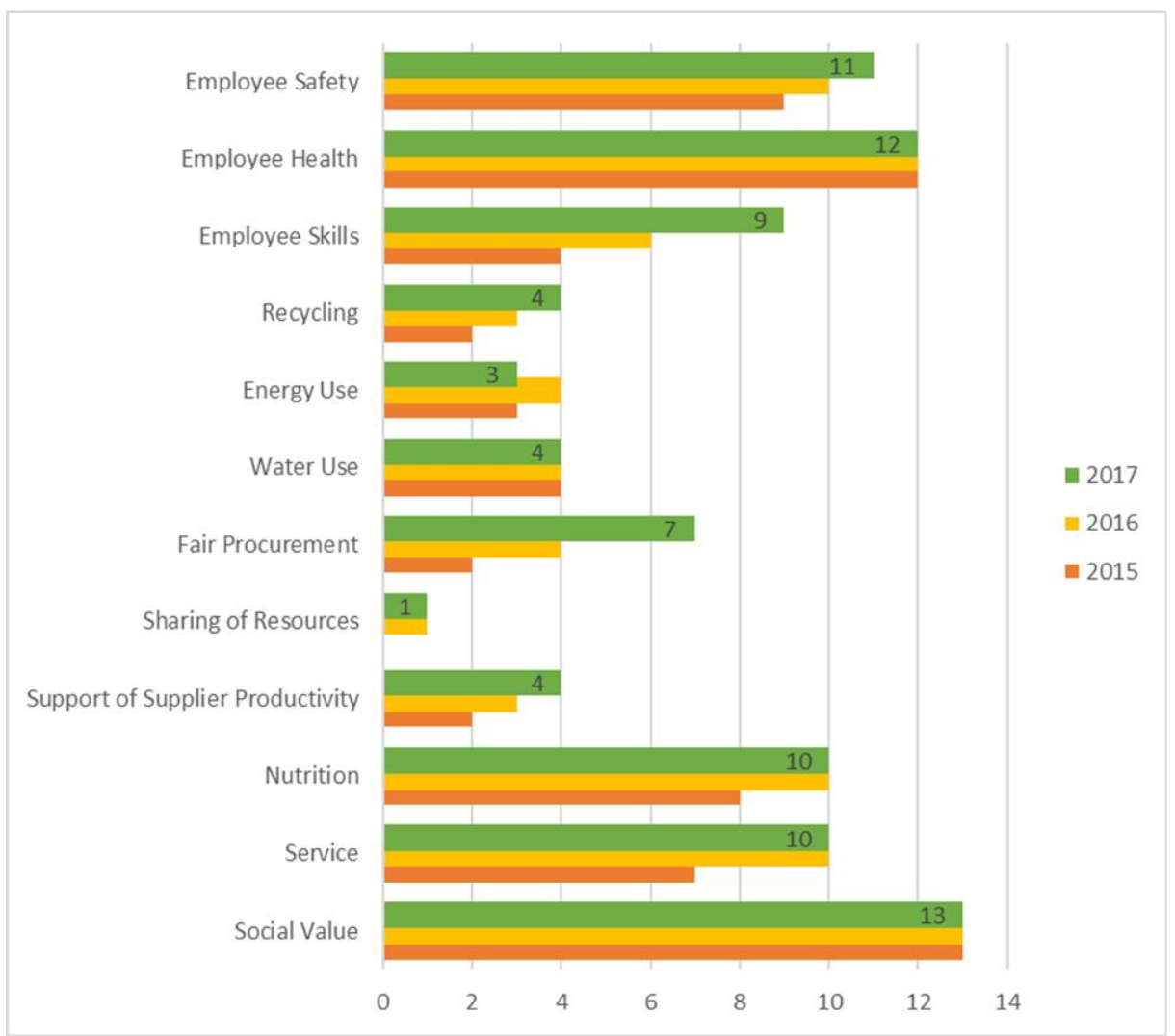

Figure 2. Shared Values by Indicator

Source: Processed Data, 2020

Notes: Analysis result by the indicator (12)

Figure 2. shows the indicators and the number of disclosing companies per year. The data shows that the customer group (nutrition, service, and social value) obtained the most disclosures from companies. The social values indicator was disclosed by all the companies each year. Surprisingly, not all the companies disclosed nutrition information, even though nutrition is closely related to food and beverage companies. As a comparison, giant food companies like Nestle, Unilever, and Danone created shared value by positioning themselves as nutrition and health companies (Pfitzer et al., 2013).

The second most disclosed group was the employee group. All the companies disclosed employee health except one. The third most disclosed group was the environment group. Environmental disclosure level is also relatively low, about 26 percent. The group obtaining the least disclosure was suppliers, disclosed by only 20 percent of the sample's companies. The least disclosed indicator is the sharing of resources with suppliers.

The company with the highest disclosure (85\%) has disclosed extensive information regarding creating shared values for its customers, employees, environment, and suppliers. That company, which owns a baby food product, creates shared values for its 
Saraswati

Creating Shared Value in the Food and Beverages Industry

Table 2. Create Shared Value by Food and Beverage

\begin{tabular}{llccc}
\hline No & \multicolumn{1}{c}{ Shared Value } & $\begin{array}{c}\text { Company } \\
\text { Disclosures }\end{array}$ & $\begin{array}{c}\text { Total } \\
\text { indicators } \\
(2015-2017)\end{array}$ & \% disclosures \\
\hline & Empoyee: & 30 & 39 & $77 \%$ \\
1 & Employee Safety & 36 & 39 & $92 \%$ \\
2 & Employee Health & 19 & 39 & $49 \%$ \\
3 & Employee Skills & & & \\
& Environment : & 9 & 39 & $23 \%$ \\
4 & Recycling & 10 & 39 & $26 \%$ \\
5 & Energy Use & 12 & 39 & $31 \%$ \\
6 & Water Use & 14 & 39 & $36 \%$ \\
& Supplier: & 2 & 39 & $5 \%$ \\
7 & Fair Procurement & & & \\
8 & Sharing of Resources & 9 & 39 & $23 \%$ \\
9 & Support of Supplier Productivity & & & $72 \%$ \\
& Customer: & 28 & 39 & $69 \%$ \\
10 & Nutrition & 27 & 39 & $100 \%$ \\
11 & Service & 39 & 39 & \\
12 & Social Value & & & \\
\hline
\end{tabular}

Source: Processed Data, 2020

Notes: The analysis results are grouped by category share value based on Drozdz et al., 2015)

customers by conducting a counselling program for mothers and pregnant women, as well as distributing free baby food to malnourished infants. The company with the highest disclosure also creates shared values for employees by providing opportunities for all employees to channel their business improvement ideas. The company has involved in government program of Pollution Control, Evaluation and Rating (PROPER) for the environmental aspect. The company encourages green behavior to the employees by reducing the use of paper and electricity. The company shared value for the supplier group by conducting mentorship and training programs for farmers and dairy cow breeders. The programs aim to promote good and sustainable agricultural practices, as well as increased quality and productivity.

Table 2. reveals CSV groups' results; there are four categories, namely employee, environment, supplier and customer. The result of this research suggests that the least disclosed came from the supplier stakeholder group, and almost all the companies analyzed did not disclose this category, except for one company, which reported the supplier category consecutively for 3 periods. The customer group is the most important stakeholder group for the food and beverage industry. The food and beverage industry have high public visibility; hence, they need to legitimize society's position. This is consistent with the legitimacy theory which suggests that companies want to align their operations with society. This finding supports Kim et al. (2019) which found that Asian businesses are customer- and society-oriented. 


\section{Conclusion}

This study analyzes the concept of creating shared value (CSV) in the food and beverage industry. Porter \& Kramer (2011) defined CSV as corporate policies and practices that enhance a company's competitiveness while simultaneously advancing the social and economic conditions in the communities of the which the company sells and operates. This study analyzed 13 listed food and beverage companies from 2015 to 2017, resulting in 39 firm-year observations. Our analysis showed that the companies created values mostly for their customers, followed by their employees, the environment, and their suppliers. Customers are especially important for food and beverage industry firms due to the stiff competitiveness in the industry. The result supports the legitimacy theory that companies need to align their operations with society's expectations to survive.

The result suggests that food and beverage companies need to start creating more shared values for society and their employees, the environment, and their suppliers. The findings of this study can provide a basic concept for future studies and basis for CSV concept. This research's limitations include limited data, resulting in only a small number of samples. The result only analysis for food and beverage company, so cannot be a generalization. Future studies are expected to use primary data to reflect a more accurate picture of CSV practices, and examine other industries as well. Future studies can examine how CSV relates to sustainable development by developing the research from Yang \& Yan (2020).

\section{References}

Akpinar, M., \& Saleem, S. (2019). Creating shared value in international business: A research agenda. Finnish Business Review, 6(December), 41-51.

Alpana. (2014). Traditional CSR Vs Creating Shared Value: A Process of Stakeholder Engagement. IOSR Journal of Economics and Finance, 3(4), 61-67.

Camarena-Martinez, J. L., Ochoa-Silva, B., \& Wendlandt-Amezaga, T. R. (2016). Exploring the Origins of Creating Shared Value in the CSR Literature. International Journal of Business and Management, 11(12), 97-109. https://doi.org/10.5539/ijbm.v11n12p97

Crane, A., Palazzo, G., Spence, L. J., \& Matten, D. (2014). Contesting the Value of "Creating Shared Value." California Management Review, 56(2), 130-154. https://doi.org/10.1525/cmr.2014.56.2.130

Daood, A., \& Menghwar, P. S. (2019). Understanding " Creating Shared Value ". 10th Annual Conference of the EuroMed Academy of Business (pp. 13-15).

Drozdz, S., Dufwa, M., Søilen, K. S., \& Meconnen, R. (2015). An Assessment of Customer Shared Value in the Restaurant Industry - a Survey from Sweden. Theoretical and Applied Economics, XXII (4605), 85-98.

Giesen, V. (2019). Creating Shared Value: Concept Clarifications and a Practical Framework (Master's thesis).

Islam, M. R., \& Hossain, S. Z. (2019). Conceptual mapping of shared value creation by the private commercial banks in Bangladesh. Asian Journal of Sustainability and Social Responsibility, 4(1), 1-20. https://doi.org/10.1186/s41180-019-0024-8

Kim, R. C., Saito, A., \& Avvari, V. M. (2020). Interpretation and integration of "creating shared value" in Asia: implications for strategy research and practice. Asian 


\section{Saraswati}

\section{Creating Shared Value in the Food and Beverages Industry}

Business and Management, 19(4), 379-406. https://doi.org/10.1057/s41291-01900064-4

Kreckova, Z. (2015). Corporate response to concept of shared value. European Scientific Journal, 11(22), 36-45.

Lapina, I., Borkus, I., \& Starineca, O. (2012). Corporate Social Responsibility and Creating Shared Value: Case of Latvia. International Journal of Social, Behavioral, Educaton, Econimic, Business and Industrial Engineering, 6(8), 2228-2234.

Macagno, T. (2013). A model for managing corporate sustainability. Business and Society Review, 118(2), 223-252.

Moczadlo, R. (2015). Creating Competitive Advantages - The European CSR-Strategy Compared with Porter's and Kramer's Shared Value. Ekonomski Vjesnik, XXVIII(1), 243-256.

Pfitzer, M., Bockstette, V., \& Stamp, M. (2013). Innovating for shared value. Harvard Business Review, 91(9), 100-107.

Porter, M. E., \& Kramer, M. R. (2006). The link between competitive advantage and corporate social responsibility. Harvard business review, 84(12), 78-92.

Porter, M. E. (2013). Creating Shared Value as Business Strategy Shared Value Continues to Gain Global Momentum. In Presentation Harvard Business School.

Porter, M. E. (2012, October). The new competitive advantage: Creating shared value. In Presentation at the HSM World Business Forum CSV. Retrieved August (Vol. 21, p. 2016).

Prasertsang, S. (2016). A Conceptual Model Of Creating Shared Value Strategy, Business Competitiveness. The 2016 WEI International Academic Conference Proceedings (pp. 135-138).

Putri, A. P., \& Triyono, A. (2020, August). Community, Dialog and Technology-Maximizing Creating Shared Value (CSV) Nestle Indonesia. In 2nd Jogjakarta Communication Conference (JCC 2020) (pp. 35-40). Atlantis Press.

Rachmawati, T., Basuki, \& Hamidah. (2019). Creating shared value (CSV): The sustainable business model. International Journal of Innovation, Creativity and Change, 8(9), 262-269.

Scagnelli, S. D., \& Cisi, M. (2014). Approaches to Shared Value Creation: CSR 2. 0 or Something More? Insights and Issues about the New Sustainability Perspective, 5(2), 10-12. https://doi.org/10.4172/2151-6219.1000e104

Setiawan, M., \& Lansink, A. G. J. M. O. (2018). Dynamic technical inefficiency and industrial concentration in the Indonesian food and beverages industry. British Food Journal, 120(1), 108-119. https://doi.org/10.1108/BFJ-04-2017-0226

Shukla, T. N. (2016). Corporate Social Responsibility through Creating Shared Value. International Journal of Current Research, 8(8), 37403-37410.

Sinthupundaja, J., \& Kohda, Y. (2019). Effects of corporate social responsibility and creating shared value on sustainability. In Green Business: Concepts, Methodologies, Tools, and Applications (pp. 1272-1284). IGI Global.

Spitzeck, H., \& Chapman, S. (2012). Academic paper Creating shared value as a differentiation strategy - the example of BASF in Brazil. Corporate Governance, 12(4), 499-513. https://doi.org/10.1108/14720701211267838

Yang, T. K., \& Yan, M. R. (2020). The corporate shared value for sustainable development: An ecosystem perspective. Sustainability, 12(6), 1-16. https://doi.org/10.3390/su12062348 